\title{
ファジィ理論を用いた景観舗装デザイン 支援システムの開発
}

\section{水野直樹*・松島 学**・溝渕 優***}

\begin{abstract}
近年，我国の舗装設計の在り方は，周辺環境に調和するために快適性などを考慮する 設計上の配慮が要求されている。本論文は，こうした社会的な要請に鑑み，設計者に対 して全面支援するシステムの開発を目指したものである. 本システムは, (1)舗装材料の データベースの構築，(2)景観パース図の作成，(3)景観評価機能を備えたシステムであ る.なお，景観評価にはファジィ理論を用いて総合評価を行うものである.

Key Words : landscape pavements, landscape design, landscape evaluation, fuzzy set theory, computer graphics
\end{abstract}

\section{1.はじめに}

我が国の高度成長期における舗装は，周辺環境には余 り目を向けられずに, 交通機能に重点が置かれ, 「早く, 安く, 大量に」をモットーに設計, 施工がなされてきた ようである.しかしながら，1970年代前半から環境破壊 が社会的問題として浮上し, 環境に関する問題が高まる につれて，それを考慮しなければならない時代に移行し ている.

このような背景から，1985 年 8 月に建設大臣官房技術 調查室より「建設省景観整備マニュアル (案)」が出版さ れている.また, 1987 年度には建設省が都市景観形成モ デル都市制度を創設し, 都市景観の整備に乗りだした。 1990 年度からは，「うるおい・緑・景観モデルまちづく り制度」に制度を改めて景観事業が積極的に進められて いる. また, 1992 年度からは, 民間を対象に「都市・建 築景観整備事業」も進められている.

これからの舗装は, 合理的・効率的なものから周辺環 境に調和した快適性や親しみやすさなどを考慮した設計 上の配慮が，要求されるものと考えられる.

景観舗装の計画の段階において, 設計者等はコン ピュータ・グラッフィクス (CG) を用いて計画を行う環 境に変化しつつある1).これは, $\mathrm{CG}$ を用いることによ り, 容易に舗装材料や色の変更等のシミュレーションが 可能になり, 予想図や模型に頼っている現状の計画環境 が大きく向上する.

しかしながら，景観の状況を説明する方法としては， 通常|明るい」,「落ちついた」などといった，あいまい

*正会員 M.S. 日本鋪道（株）関西支店試験所

(云575 四条畷市美田町 5-1)

${ }^{* *}$ 正会員 工博 東電設計（株）技術開発本部 耐震技術部 課長

***正会員 工博 日本鋪道（株）技術研究所 第一研究室室 長
表現が多く用いられている2. そのため, 各個人によって 判断基準が明確でないため認識に差が生じる。 また, 景 観は専門家の主観的な感覚や経験に大きく依存して評価 されている，つまり，評価項目とその評価基準や評価レ ベルのランクの境界が明確ではなく, その評価のプロセ スが個人により相違することが，理由として考えられ る. そのため, 評価自体を定量的に求めることは, 今ま での確定論的な判断基準では難しい，従って，今まで定 常的に行ってきた客観的な評価手法を確立するのではな く, 主観的な立場での評価手法を確立するほうが良いと 考えられる。

主観的な不確実性問題を数学的に取り扱う手法として ファジィ集合の概念を用いた研究報告が近年多くの分野 で報告されている. 白石・古田ら ${ }^{3), 4)}$ はコンクリート橋の 床版の劣化モデルの判断にファジィ理論に基づいたエキ スパート・システムの開発を行っている. また, 清水ら ${ }^{5)}$ は岩盤の等級区分にファジィ理論を応用し，その適合性 を評価している. 筆者らの一人 ${ }^{6)}$ 海岸施設の劣化診断 にファジィ理論に基づいた診断手法の提案を行ってい る. 舗装分野においては, 姫野”) ${ }^{3)}$ らが路面性状の評価 に, ファジィ数量化理論 II 類を用いて評価手法の提案を 行っている.

本研究では, 景観舗装デザインを全面支援するシステ ムの開発を目的としている。本システム（HIGINS： Harmonic Ideal Graphics for Integrated Nippo Systems）は，(1)景観舗装材料のデータベース機能，(2)CG を用いた景観パース図の作成機能，(3)作成された景観 パース図に対する景観評価機能を備えたシステムであ る. なお，景観評価は，（a）色彩調和，（b）周囲景観之 の調和,（c）舗装材料の施工場所への適合性，（d）舗装 材料の性能，（e）舗装材料のイメージの 5 項目に対して 全体評価を行うものである.

本システムにより, 景観舗装デザインに対して専門知 
識のないエンドューザでも景観舗装材料の選択から景観 パース図の作成，及びその景観評価を含めた景観舗装デ ザインを行うことが可能となる。

\section{2. システム設計}

\section{（1）ハードウェア設計}

本研究で開発したシステムの概要を図一1に示す．本 システムは，ホスト・コンピュータに 32 ビット（MC $68040,25 \mathrm{MH}_{2}$ ) の Apple 社の Macintosh Quadra700 を選定した。本機種は，マウス入力によるキーボードレ スの操作環境を備えたパーソナルコンピュータである.

景観パース図をより現実的で信頼性の高いものにする ため，フルカラー対応（約 1670 万色）とした．他に，入 力機器として, 施工写真や景観舗装材料の写真を取り込 むスキャナーを，作成された景観パースの出力機器とし てカラープリンターを選定した。

\section{（2）ソフトゥェア設計}

a）データベース機能

開発したデータベース機能によれば，施工場所や利用 者のニーズを満足する景観舗装材料を検索することが可 能である．データベース機能のメイン入力画面を写真一 1 の（a）に示す．景観舗装材の画像データの登録，及び 検索条件の入力をマウスにより操作可能な環境である.

データベースに登録される属性デー夕は下記の 5 つの 項目に分類した.

(1) 景観舗装材料の種別

(2) 景観舗装材料の施工場所への適合性

(3) 景観舗装材料のイメージ

(4) 景観舗装材料の性能

(5) その他（標準舗装構成，施工事例など）

(1)の景観舗装材料の種別は，色彩やデザインの自由度 が高い自然系材料の石や土を用いた舗装，二次製品のブ ロックやタイルを用いた舗装，そして高分子材料を用い たカラー舗装等に分類できる．筆者らは形態及び施工方 法から 34 種類に分類した

(2)の景観舗装材料の施工場所への適合性に関しては, 写真一1の（b）に示すように景観舗装の施工場所を 12 箇所に分類し，それらへの適合性を 4 段階（最適・適・ 条件付可・不適）に分割した。

(3)の景観舗装材料のイメージに関しては，写真一1の

（c）に示すように，景観を評価する上で必要と思われる 26 個の景観評価用語を設定し，評価尺度を 5 段階に分割 した ${ }^{10)}$

(4)の景観舗装材料の性能に関しては, 写真一1の (d) に示すように，美観，歩行性，予算など景観評価に必要 と思われる 26 個の評価用語を設定し, 評価尺度を 5 段 階に分割した ${ }^{9}$.

(5)のその他の項目に関しては，その景観舗装材料に関

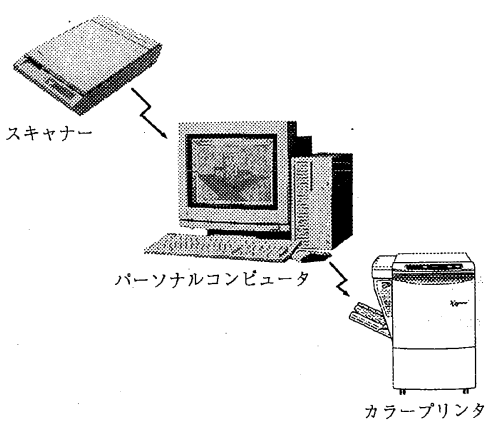

図一1 ハードウェアの概要

する情報として，標準舗装構成，施工事例などを入力で きるように設定した，写真一1の（e）は標準舗装構成の

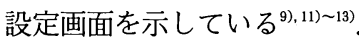

データベースからの検索では，下記の 5 つの検索条件 の組み合わせが可能である ${ }^{9)}$.

(1) 景観舗装材料の種別

(2) 景観舗装材料の性能

(3) 景観舗装材料の施工場所への適合性

(4) 景観舗装材料と施工場所の色彩調和

(5) 設計区分

b）景観パース図作成機能

CG を用いた景観パース図の作成機能では，景観舗装 の敷設パターンの作成や，その敷設パターンを施工場所 の写真画像にはめ込むことが可能である.

写真一2の（a）は施工場所の現状の景観写真を示して いる．その路面は掘削による凹凸，継ぎ接ぎ，色ムラな どが目だち，改修が急がれるべき状態にあるといえる.

写真一2の（b）は，データベースから検索された景観舗 装材料の一つを示している。 その景観舗装材料を用いて 敷設パースを写真一2の (c) のように作成する. そして, その敷設パースを景観写真画像にはめ込んだものが写真 -2 の (d) である. CG を用いることにより，景観舗装 材料やその色の変更む容易である．写真一2の（e）に同 時に景観舗装材料や色の変更を行った例を示す.

なお，これらの CG 機能は，既往の画像処理ソフト ウェアの Photoshop ${ }^{14)} と$ Studio32 ${ }^{15)}$ を用いた。

c）景観評価機能

作成された景観パース図に対して，景観評価をつァ ジィ理論を用いて行う機能を開発した。景観舗装の評価 は，色彩調和やイメージなどから評価されるむのであ る。 そのため，これらの各評価項目は，一般的に定性的 な表現によるものが多い2. に対する判定が，評価者の主観に依存している各個人の ばらつき（あいまいさ）を考慮して景観評価を行う手法 を開発するむのである。 


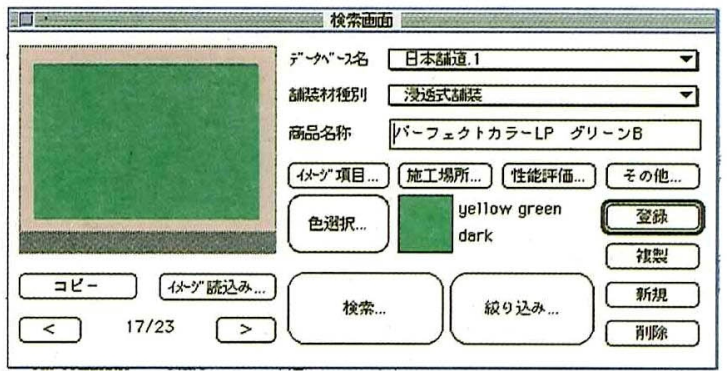

（a）データベース機能のメイン入力画面

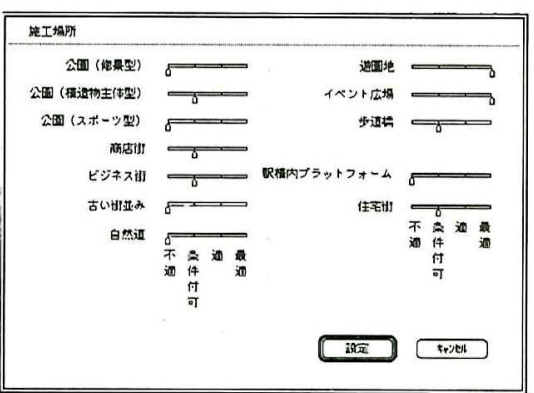

(b) 施工場所の適合性に関する入力画面

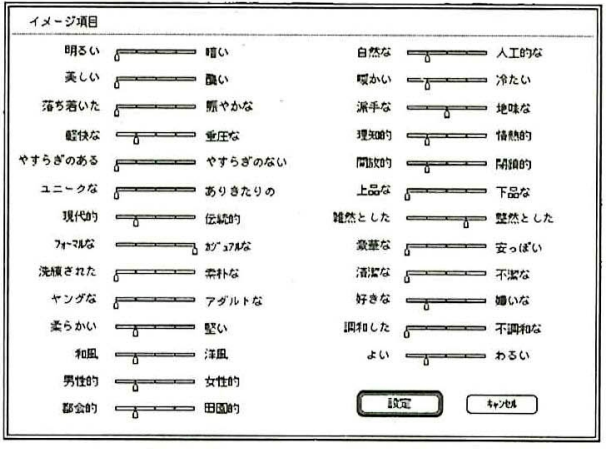

(c) 舖装材料のイメージに関する入力画面

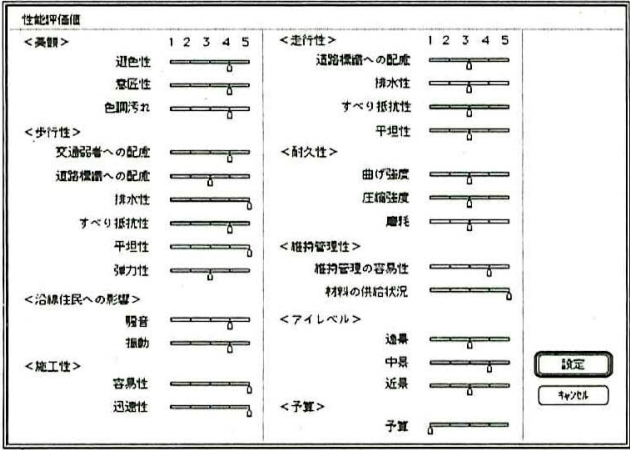

（d）䟣装材料の性能に関する人力画面

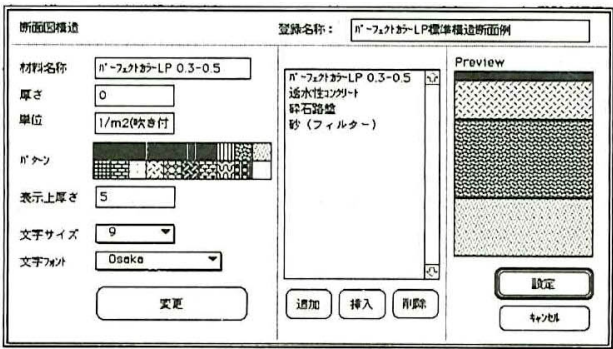

（d）舖装材料の櫒汻舖装模成の人力画面

写真一1 データベース機能の入力画面

\section{3. 評価プロセス}

\section{（1）景観評価の分類項目}

景観評価項目は下記の 5 項目とした ${ }^{9}$.

(1) 色彩調和

(2) 周囲景観との調和

（3）景観舗装材料の施工場所への適合性

(4) 景観舗装材料の性能

(5) 景観舗装材料のイメージ

各評価項目の評価レベル $L$ を表一1 に示す. 本評価で は, 各評価項目の評価レベルを I 〜 V 5 段階に区別し た. 写真一3は，本景観評価機能で評価を行うための入 力画面を示している. なお, 写真一3の (a) は, 評価し
たい景観舗装材料（景観パース作成の時に使用した舗装 材料なよ゙）をデータベースから選択した後に表示される メイン入力画面である.

(1)の色彩調和に関しては，施工場所の主景観の色と景 観舗装材料の色の調和を評価するむのである. 17〜 18世 紀頃から, 調和に関する配色の形式が経験的に示されて おり極く近いか対照的な色どうしで調和が生じるとされ ている ${ }^{16)}$. 筆者らは色彩調和の評価基準として, 下記に 示す 3 つの調和のパターンで行った ${ }^{16)}$.

(a) 同系 (色相・トーン) の調和

（b）類似（色相・トーン）の調和

(c) 対照（色相・トーン）の調和

写真一3の（a）に, 設定された主景観の色と舗装材料 


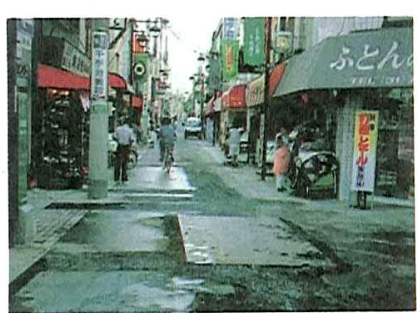

(a) 施工前の写真画像

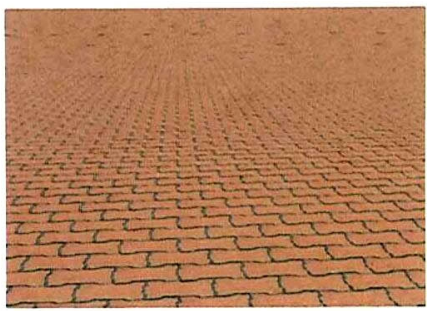

(c) パースの作成
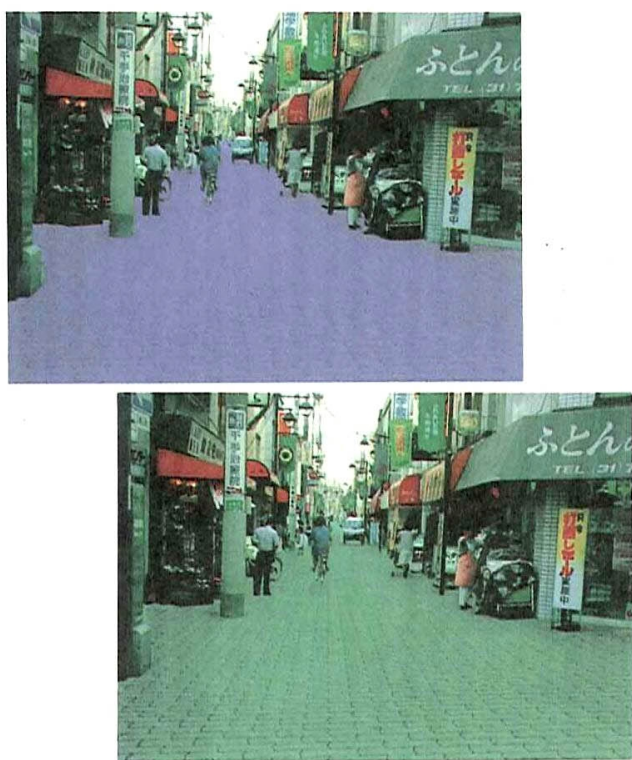

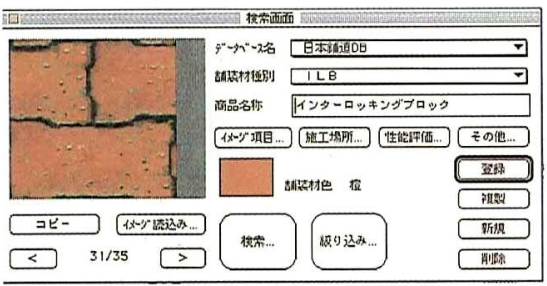

(b) データベースで検索された出力画面

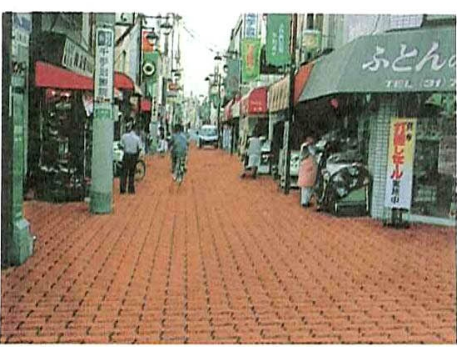

（d）施工写真にはめ込んだ画像
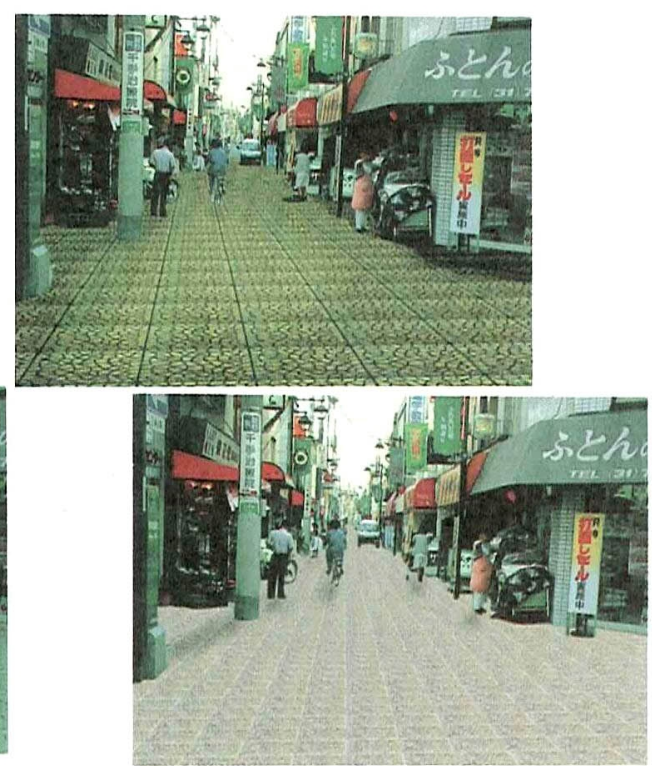

（e）色や舖装材を変更した写真画像

写真一2 景観パース図作成の流れ

の色を示している．この設定された色を図一2に示すよ うに明度を 3 段階，彩度を 8 段階，そして色相を円座標 で分類して色彩調和の評価を行った。評価レベル $L$ は, 図一2 に示した判定基準を基に表一1 に示すように決定 される。

(2)の周辺環境との調和に関しては，写真一3の（b)"に 示すようにユーザに 10 個の質問を行い 5 段階で評価す るように設定した。 そして評価レベル $L$ は，ユーザから 得られた点数の総和を基に表一 1 に示すように決定され る.
(3)景観舗装材料の施工場所への適合性，(4)景観舗装材 料の性能，(5)景観舗装材料のイメージに関しては，デー 夕ベースに構築された属性デー夕の情報を基に, 各項目 の評価レベル $L$ を決定する.

(3)の景観舗装材料の施工場所への適合性に関しては, 評価したい舗装材料の属性デー夕を基に, 評価レベル $L$ を表一1 に示すように決定する．例えば，今回は商店街 を対象とした景観舗装デザインである。そして評価した い舗装材料の属性データである「施工場所への適合性」 の中で商店街の適合性が「最適」之設定されていれば評 
表一1 評価項目と評価レベル

\begin{tabular}{|c|c|c|c|c|c|}
\hline $\begin{array}{c}\text { 評価 } \\
\text { レベル } \\
\text { L }\end{array}$ & $\begin{array}{c}\text { 色彩調和 } \\
X_{1 L}\end{array}$ & $\begin{array}{c}\text { 周囲景観との } \\
\text { 調和 } \\
X_{2 L}\end{array}$ & $\begin{array}{c}\text { 舗装材料の施工 } \\
\text { 場所適合性 } \\
X_{3 L}\end{array}$ & $\begin{array}{c}\text { 舖装材料の } \\
\text { 性能評価 } \\
X_{4} \text { L }\end{array}$ & $\begin{array}{c}\text { 舗装材料の } \\
\text { イメー訬価 } \\
X_{5}\end{array}$ \\
\hline V & $\begin{array}{l}\text { 色彩調和に適合 } \\
\text { している } \\
\text { (明度と彩度, } \\
\text { およ゙色相が調 } \\
\text { 和しててるい位㯰 } \\
\text { にある) }\end{array}$ & $\begin{array}{l}\text { 地域個性の表現 } \\
\text { 周辺環境との } \\
\text { 調和を充分に考 } \\
\text { 虑している } \\
\text { (得点の総和が } \\
40 \text { 上55以下で } \\
\text { ある) }\end{array}$ & $\begin{array}{l}\text { 最適な舗装材が } \\
\text { 選定されている } \\
\\
\text { (属性データで } \\
\text { 「最」適」が設定 } \\
\text { されている) }\end{array}$ & $\begin{array}{l}\text { 性能評価を充分 } \\
\text { に満足している } \\
\text { (評価得点Aが } \\
85 \text { 以上100以下 } \\
\text { である) }\end{array}$ & 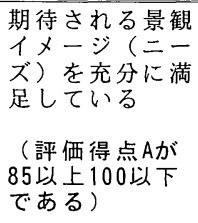 \\
\hline IV & $\begin{array}{l}\text { 色彩調和に近い } \\
\text { るで適合してい } \\
\text { (明度と彩度, } \\
\text { また包相のいい } \\
\text { つが調和してい } \\
\text { る位置にある) }\end{array}$ & 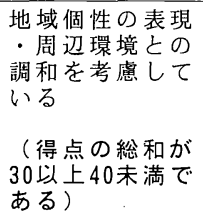 & $\begin{array}{l}\text { 適用可能な舗装 } \\
\text { 材が選定されて } \\
\text { いる } \\
\text { (属性データで } \\
\text { †適」が設定さ } \\
\text { れてい) }\end{array}$ & $\begin{array}{l}\text { 性能評価を満足 } \\
\text { しいる } \\
\text { (評価得点Aが } \\
65 \text { 上 } 85 \text { 末満で } \\
\text { ある) }\end{array}$ & 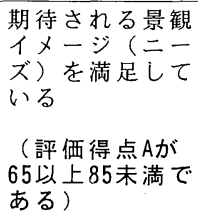 \\
\hline III & $\begin{array}{l}\text { 色彩調和に適合 } \\
\text { していない } \\
\text { (明度と彩度, } \\
\text { およ゙色相が調 } \\
\text { 和してていい位 } \\
\text { 置にある) }\end{array}$ & $\begin{array}{l}\text { 地域個性の表現 } \\
\text { 周辺環境を考 } \\
\text { 虑している点が } \\
\text { 見られない } \\
\text { (得点の総和が } \\
\text { 10以上30末満で } \\
\text { である) }\end{array}$ & $\begin{array}{l}\text { 条件付きで適用 } \\
\text { 可能な舗装材が } \\
\text { 選定されている } \\
\text { (属性データで } \\
\text { 「条件付き可」 } \\
\text { が設定されてい } \\
\text { る) }\end{array}$ & $\begin{array}{l}\text { 性能評価をやや } \\
\text { 満足している } \\
\text { (評価得点Aが } \\
45 \text { 以上 } 65 \text { 末満で } \\
\text { ある) }\end{array}$ & 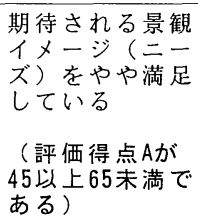 \\
\hline II & & & $\begin{array}{l}\text { 不適用な舗装材 } \\
\text { が選定されてい } \\
\text { る } \\
\text { (属性データで } \\
\text { 「不適」が設定 } \\
\text { ている) }\end{array}$ & $\begin{array}{l}\text { 性能評価を満足 } \\
\text { ていない点が } \\
\text { 多い } \\
\text { (評価得点Aが } \\
30 \text { 以上45末満で } \\
\text { ある) }\end{array}$ & $\begin{array}{l}\text { 景観イメージをていない } \\
\text { 洅足していい } \\
\text { 点が多い } \\
\text { (評価得点Aが } \\
30 \text { 以上 } 45 \text { 末満で } \\
\text { ある) }\end{array}$ \\
\hline I & & & & $\begin{array}{l}\text { 性能評価を満足 } \\
\text { していない } \\
\text { (評価得点Aが } \\
20 \text { 上 } 30 \text { 末満で } \\
\text { ある) }\end{array}$ & $\begin{array}{l}\text { 景観イメージを } \\
\text { 满していない } \\
\text { (評価得点Aが } \\
\text { 20以上30末満で } \\
\text { ある) }\end{array}$ \\
\hline
\end{tabular}

注意：（太字）内は，ユーザ入力によって決定される評価判定基準

価レベルは $V$ と決定される.

(4)の景観舗装材料の性能に関しては，評価したい舗装 材料の属性デー夕を基に, 評価レベル $L$ を式（1）を用 いて表一1のように決定する.

$$
A=\frac{\sum_{i=1}^{p}\left(a_{i}\right)}{5(p)} \times 100
$$

ここで, $A$ : 評価得点,

$a ：$ 選択された属性データの得点

$$
(a=1,2,3,4,5),
$$

$p ：$ ユーザがニーズとして選択した項目数

(5)景観舗装材料のイメージに関しては，同様に評価し たい舗装材料の属性データを基に, 評価レベル $L$ は式

（1）を用いて表一1 に示すように決定する.なお，この 景観舗装材料のイメージに関しては，図一3に示すよう な属性デー夕の得点とした。 すなわち, 属性データで図 一3の（a）のように設定されていた場合, 景観評価の入 力で「明るい」を選択すれば得点は 4 点になり, その反 対に「暗い」を選択すれば 2 点となる.
これらの各評価項目の評価判定基準は, 定性的に表現 されるものである。そのため, 評価区分の境界は明確で はない，例えば，「舗装材料の性能」の評価項目に関し て, 評価レベルIVの「性能を満足している」と評価レべ ル III の「性能をやや満足している」の境界の判断は, 各 専門家の主観的な経験と感覚に大きく依存しているた め, 明確ではない.このあいまいさを考慮するために ファジィ集合として表現することが一つの工学的な手法 として考えられる.

本評価機能では，評価判定区分を区間 $[0.0 \sim 4.0]$ の 8 分割とし，式（2）に示す全体集合とした.

$$
C_{N}=\{0.0,0.5,1.0, \cdots \cdot 3.5,4.0\}(N=0 \sim 8)
$$

ここで, 全体集合 $C_{N}$ の要素は, 景観評価レベル $L （ \mathrm{I}$ 〜 Vのレベルを意味する. 以降, 全体評価レベルと呼称 する）を示す指標である.この $C_{N}$ の值が高い值を与え た場合は，景観評価が優れており，反対に低い值を与え た場合は，景観評価が劣っていることを意味する．表一 2 に全体評価レベルの評価判定区分を示す．なお，本評 


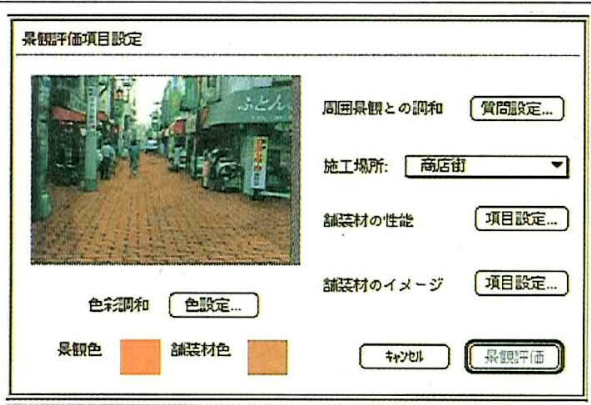

(a) 景钼評価のメイン入力画面

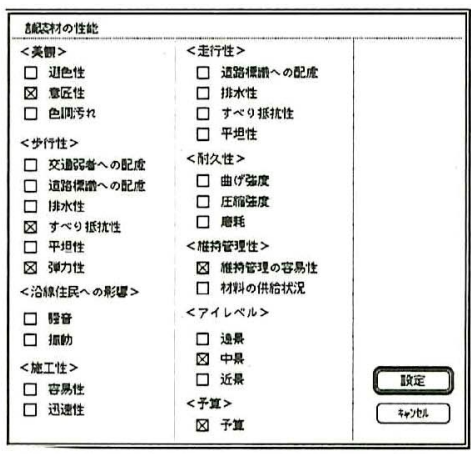

（c）舗装材の性能に関する景钼铗価の入力画面

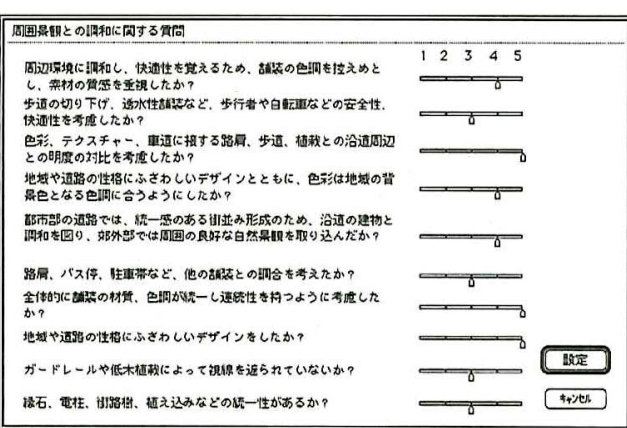

（b）周囲景钼との調和に関する景钼評価の入力画面

\begin{tabular}{|c|c|c|c|c|c|}
\hline \multicolumn{6}{|l|}{ 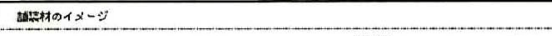 } \\
\hline 朋 64 & 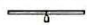 & Wus & 自勧法 & $\gamma$ & NInta: \\
\hline 龵(い) & ए & a & 㱠心 & 5 & 部心 \\
\hline 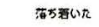 & & 同や゚かな & 强手右 & $=$ & = \\
\hline 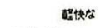 & $\pi$ & 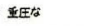 & 396003 & r & $=1$ tantats \\
\hline やすらさののる & & やオらす゚のるい & 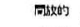 & 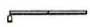 & $=$ \\
\hline エニーカな & & カタタたりの & 上品告 & $\gamma$ & F品表 \\
\hline $3 R_{1}(+\infty)$ & r- & 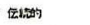 & Regercした & 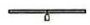 & $=2$ \\
\hline$x-3 \times 2$ & $\pi$ & IS 2AS & 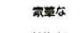 & $t$ & 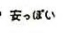 \\
\hline 洗就 हैत & g & $=$ 叔 & 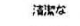 & $\tau$ & F⿻上丨 \\
\hline 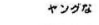 & $\bar{y}$ & フダルトな & 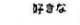 & 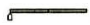 & $=\operatorname{coc} 15$ \\
\hline 5 acc & $\tau$ & gxa & $\mathbb{B r}: 0\llcorner\pi$ & 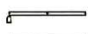 & 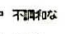 \\
\hline 和四 & $\sigma$ & 洋 & $\$ \omega$ & 5 & わろい \\
\hline 男的 & $\pi$ & 女्र被的 & & & \\
\hline 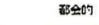 & $\%$ & 田国的 & & 征 & $5+\%$ \\
\hline
\end{tabular}

(d) 沾装材のイメージに関する入力画面

写真一3 景観評価の入力画面

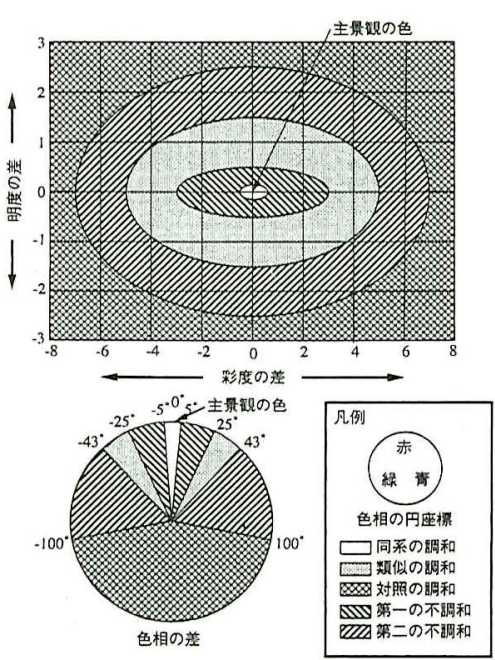

図一2 色彩調和の判定基準

価においては，表一1の評価判定区分をそのままファ ジィ集合として変換できるあのと仮定している.ここ で, 各評価項目における評価レベル $X_{i L}$ ごとの帰属度関 数を $\mu_{X i L}\left(C_{N}\right)$ と表す. 各評価項目の帰属度関数 $\mu_{X i L}\left(C_{N}\right)$ を図一4（a）～(e) に示し, 全体評価レベルの帰属度関 数 $\mu_{Z L}\left(C_{N}\right)$ を図一 4 (f) に示す。なお, 帰属度関数は, 技術者らが主観的に設定できるむのであり，この帰属度 関数の設定の違いにより, 評価判定区分の選択に関する
明るい!

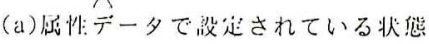

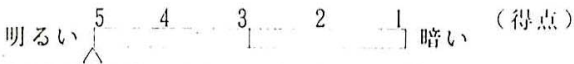

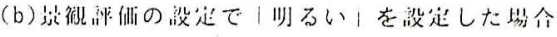

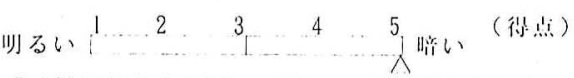

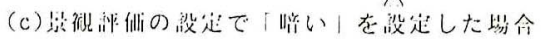

図一3 イメージ評価の属性データの得点

あいまいさを定量的に反映することが可能である.

\section{（2）評価項目の重要度の設定}

景観評価において各評価項目には相関があり，また各 評価項目の重要度は異なっていると考えられる. そこ で, 各評価項目に対して $[0,1]$ 間で重みを与える重要度 係数 $W_{i}$ を設定した. この重要度係数の值が高いほど, その評価項目は重要であり，その反対に重要度係数の値 が低いほど，その評価項目は重要でないことを意味す る.これらの值は, 各個人の主観的な判断により設定さ れるあのである.ここでは，筆者らの経験的な判断から 表一3 に示すような值を設定した.

\section{（3）全体評価レベルのファジィ期待值の評価}

a）全体評価レベルのファジィ集合

各評価項目の判定結果汃ら全体評価レベルの期待值を 求める手法を説明する. 一般に, この決定は各個人の主 観により設定されるもので, その最終の全体評価レベル 
表一2 景観評価（全体評価）レベル $L$ の内容

\begin{tabular}{|c|c|c|c|c|}
\hline $\mathrm{V}$ & IV & III & II & I \\
\hline $\begin{array}{l}5 \text { 項目全てを考 } \\
\text { 慮した舖装材が } \\
\text { 選定されおり } \\
\text { 全く問題はないな }\end{array}$ & $\begin{array}{l}\text { 若干問題がある } \\
\text { が舗装材の選定 } \\
\text { は, 良好とみな } \\
\text { される }\end{array}$ & $\begin{array}{l}\text { 問題は多いが舗 } \\
\text { 装材の選は, } \\
\text { 変更するまでに } \\
\text { は至らないな }\end{array}$ & $\begin{array}{l}\text { 舖装材の選定に } \\
\text { 問題があ若干 } \\
\text { 修正や変を } \\
\text { 必要とする }\end{array}$ & $\begin{array}{l}\text { 舖装材の選定に } \\
\text { 問題がある多く } \\
\text { 修正や変更を } \\
\text { 必要とするる }\end{array}$ \\
\hline
\end{tabular}
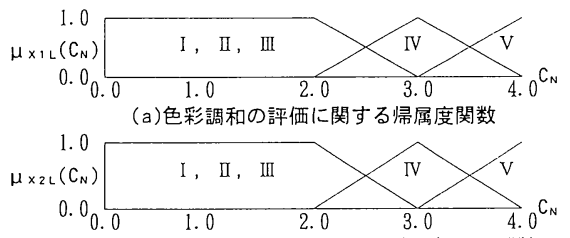

(b)周囲景観との調和の評価に関する帰属度関数

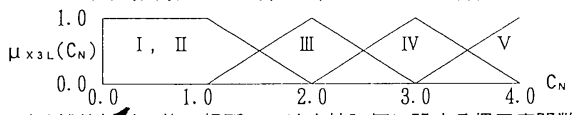

(c)舗装材科の施工場所への適合性評価に関する帰属度関数

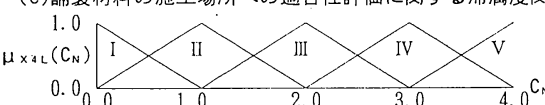

(d)舗装材料の性能評価に関する帰属度関数
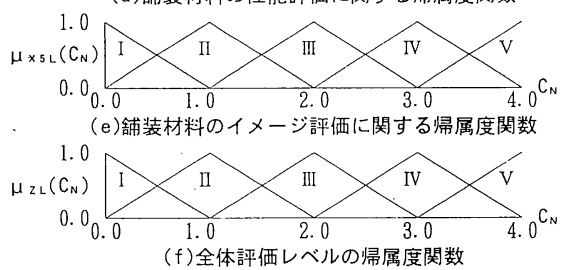

図一4 設定された帰属度関数

表-3 各評価項目における重要度係数

\begin{tabular}{|l|l|l|l|l|l|}
\hline 評価項目 $X_{i L}$ & $X_{1 L}$ & $X_{2 L}$ & $X_{3 L}$ & $X_{4 L}$ & $X_{5 L}$ \\
\hline 重要度係数 $W_{i}$ & 1.0 & 0.5 & 0.8 & 0.8 & 1.0 \\
\hline
\end{tabular}

の判定に対する思考過程を説明することは難しい. 本景 観評価機能では，この過程を明確に表現するため，ファ ジィ理論を用いて全体評価レベルのファジィ期待值を求 める.

各評価項目の判定結果と重要度俰数を用いることによ り画像処理された景観パースなどに対してのファジィ集 合を求める.すなわち，対象とする景観パースなどの景 観評価（全体評価）レベルの程度を表す $\mu_{R}\left(C_{N}\right)$ （以降, 対象とする景観の全体評価レベルと称する）は，各評価 項目で得られた評価レベル $L$ の帰属度関数 $\mu_{X i L}\left(C_{N}\right)$ 之 その重要度係数 $W_{i}$ を用いて求める. 対象とする景観の 全体評価レベル $\mu_{R}\left(C_{N}\right)$ は式（3）のように定義した.

$$
\mu_{\mathrm{R}}\left(C_{N}\right)=\stackrel{8}{i=0}^{\vee} W_{i} \cdot \mu_{X i}\left(C_{N}\right)
$$

ここに, $\mu_{R}\left(C_{N}\right)$ : 対象とする景観の全体評価レベルの州 属度関数

$W_{i}$ : 評価項目 $i$ における重要度係数,

$\mu_{X i L}\left(C_{N}\right)$ : 評価項目 $i$ における評価レベル $L$ の帰 属度関数
例えば, $X_{1 L}$ : 色彩調和 $(L=\mathrm{III}), X_{2 L}$ : 周りとの景観 との調和 $(L=\mathrm{IV}), X_{3 L}$ : 施工場所 $(L=\mathbb{I I I}), X_{4 L}$ : 舗装 材の性能 $(L=\mathrm{IV}), X_{5 L}$ : 舗装材のイメージ $(L=\mathbb{I I I})$ と 判断された場合の $X_{i L}$ の各帰属度関数 $\mu_{X i L}\left(C_{N}\right)$ 之, その 結果から得られた対象とする景観の全体評価レベル $\mu_{R}\left(C_{N}\right)$ を図一 5 , 及び表一 4 に示す.

b) ファジィ測度

ファジィ集合は, その対象とする意味のあいまいさを 表現しているのに対して, ファジィ測度は判定結果のあ いまいさを表現するあのである ${ }^{177.187 .}$ ，本システムの景観 評価機能では, $\lambda$ ファジィ測度を評価尺度として用い る. $\lambda$ ファジィ測度は $\lambda$ を係数として式 (4) で表現さ れる. ${ }^{(1), 187}$.

$$
\left\{\begin{array}{l}
g_{\lambda}\left(E_{i}\right)=g_{i} \\
g_{i=0}\left(E_{i}\right)=g_{i}+g_{\lambda}\left(E_{i-1}\right)+\lambda \cdot g_{i} \cdot g_{\lambda}\left(E_{i-1}\right) \\
i>0(-1<\lambda<\infty, i=0>8)
\end{array}\right.
$$

ここで, $E_{i}=\left\{C_{0}, C_{1}, C_{2}, \cdots \cdot C_{\mathrm{i}}\right\}$ であり; $C_{N}$ の部 分集合である.

また, $g_{i}$ はファジィ密度 $\left(0.0<g_{i}<1.0\right)$ を意味し, 式 （5）で表される.

$$
g_{i}=\alpha \cdot \mu_{\mathrm{R}}\left(C_{i}\right)
$$

ここで， $\alpha$ は $g_{i}$ を正規化するための定数であり，係数 $\lambda$ を与えた後に, 式（6）で求められるあのである.

$$
1= \begin{cases}\sum_{i=1}^{8} g_{i} & \lambda=0.0 \\ \lambda^{-1}\left[\prod_{i=1}^{8}\left(1+\lambda \cdot g_{i}\right)-1\right] & \lambda \neq 0.0\end{cases}
$$

式 (6) は $\lambda$ と $g_{i}$ の制約式であり， $\lambda$ を係数として $E_{i}$ の重複する度合いを示す尺度である。 すなわち， $\lambda$ が 0 より大きい場合は，優加法的となり評価レベルが高い.も のを重視する結果を与える. その反対に入が 0 より小さ い場合は, 劣加法的となり評価レベルが低いむのを重視 する結果を与える. また, $\lambda$ の值が 0 の場合は, 単に加 法的となり入ファジィ測度と確率測度は一致する値を 与える ${ }^{17), 18)}$.

前記の例では $\lambda$ の值が 0 の場合は， $\alpha$ は 0.149 の值と なる. そして, $g_{i}$ の値は, 表一 5 に示す通りである.

c）ファジィ積分による全体評価レベルの評価

景観評価は, 各評価区分の帰属度関数を被積分関数之 するファジィ積分によって計算する。 つまり, 測度が与 えられると積分概念が得られる. そして, ファジィ期待 值というのは, ファジィ測度によるファジィ積分であ 


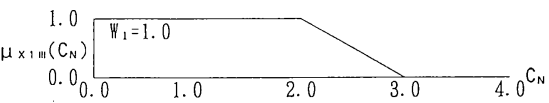

(a) X ↔が選択された帰属度関数

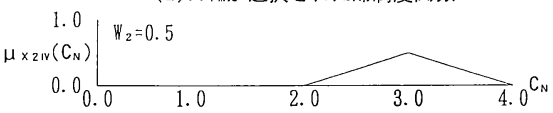

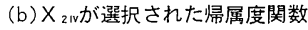

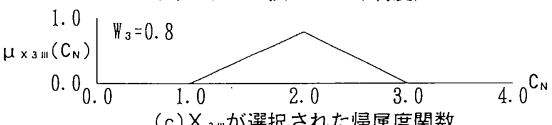

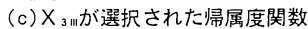

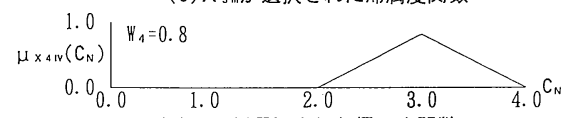

(d) X 4 wが選択された帰属度関数

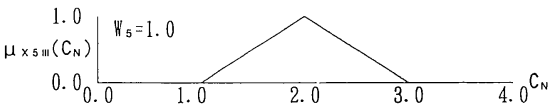

(e) $X_{5}$ แが選択された帰属度関数

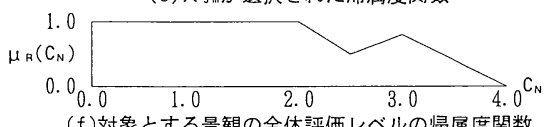

(f)対象とする景観の全体評価レベルの帰属度関数

図一 5 州属度関数の例

表一4 各 $\mathrm{C}_{\mathrm{N}}$ における $\mu_{\mathrm{R}}\left(\mathrm{C}_{\mathrm{N}}\right)$ の值

\begin{tabular}{|c|c|c|c|c|c|c|c|c|c|}
\hline $\mathrm{C}_{\mathrm{N}}$ & 0.0 & 0.5 & 1.0 & 1.5 & 2.0 & 2.5 & 3.0 & 3.5 & 4.0 \\
\hline$\mu_{\mathrm{R}}\left(\mathrm{C}_{\mathrm{N}}\right)$ & 1.0 & 1.0 & 1.0 & 1.0 & 1.0 & 0.5 & 0.8 & 0.4 & 0.0 \\
\hline
\end{tabular}

る $^{17), 18)} \cdot g_{\lambda}\left(E_{i}\right)$ は式 $(4)$ から $\mu_{R}\left(C_{N}\right)$ によって求めら れる.ファジィ期待值の $F(L)$ は, 全体評価レベルの帰 属度関数 $\mu_{z L}\left(C_{N}\right)$ を $g_{\lambda}\left(E_{i}\right)$ で積分することにより得ら れる. したがって, 各全体評価レベル $L$ ごとのファジィ 期待值 $F(L)$ は，式 (7) で示される ${ }^{17), 18)}$.

$$
\begin{aligned}
F(L) & =\oint_{\mu_{z L}} \cdot g_{\lambda} \\
& =\bigvee_{i=0}^{8}\left[\left(\bigwedge_{n=0}^{i} z L\right.\right. \\
z & \left.\left.\left(C_{N}\right)\right) \wedge g_{\lambda}\left(E_{i}\right)\right]
\end{aligned}
$$

式 ( 7$)$ で, $\mu_{z L}\left(C_{N}\right)$ の順番を $\mu_{z L}\left(C_{0}\right)>\mu_{z L}\left(C_{1}\right)>\mu_{z L}$ $\left(C_{2}\right)>\cdot ・>\mu_{Z L}\left(C_{8}\right)$ となるように並び換えを行う. 前記の例で各レベル毎に並べ換えを行った值は, 表一6 に示す通りである. そして, $C_{N}{ }^{(L)}=\left\{C_{0}{ }^{(L)}, C_{1}{ }^{(L)}, C_{2}{ }^{(L)}\right.$, ・・・, $\left.C_{8}^{(L)}\right\}$ になるようにすると式 $(7)$ は式 $(8)$ の ように変換できる.

$$
F(L)=\vee_{i=1}^{8}\left[\mu_{Z L}\left(C_{i}^{(L)} \wedge g_{\lambda}\left(E_{i}^{(L)}\right)\right]\right.
$$

ここで, $E_{i}{ }^{(L)}=\left\{C_{0}{ }^{(L)}, C_{1}{ }^{(L)}, C_{2}{ }^{(L)}, \cdots \cdot C_{i}{ }^{(L)}\right\}$ 屯 $\mu_{z L}$ $\left(C_{N}\right)$ ，の大きい順序に各評価レベル $L$ ごとに並び換えを 行ったものである.

前記の例で, 各レベルごとに $C_{N}{ }^{(L)}$ の並べ換えを行っ た $E_{i}{ }^{(L)}$ の值は, 表一6に示す通りである. そして, 式 (4) を用いて計算された, 各レベルごとの $g_{\lambda}\left(E_{i}\right)$ の值 は, 表一6 に示す通りである.

なお, 表一6, 及び式 $(8)$ 加求めた $F(L)$ は, 表

表一5 各 $C_{N}$ における $g_{i}$ の值
\begin{tabular}{|l|l|l|l|l|l|l|l|l|l|}
\hline$C_{N}$ & 0.0 & 0.5 & 1.0 & 1.5 & 2.0 & 2.5 & 3.0 & 3.5 & 4.0 \\
\hline$g_{i}$ & 0.149 & 0.149 & 0.149 & 0.149 & 0.149 & 0.075 & 0.119 & 0.060 & 0.000 \\
\hline
\end{tabular}

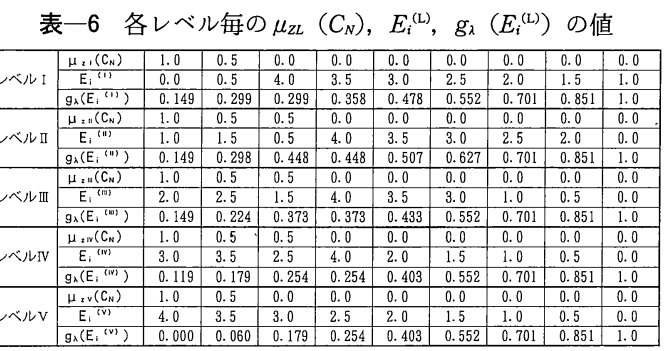

\begin{tabular}{|c|c|c|c|c|c|}
\multicolumn{7}{c|}{ 表一7 $F(L)$ の值 } \\
\begin{tabular}{|c|c|c|c|c|c|}
\hline レベル & I & II & III & IV & V \\
\hline$F(L)$ & 0.299 & 0.448 & 0.373 & 0.254 & 0.060 \\
\hline$F(L)(\%)$ & 20.8 & 31.3 & 26.0 & 17.7 & 4.2 \\
\hline
\end{tabular}
\end{tabular}

一7に示す通りである.

ファジィ理論による評価結果は各評価レベルの期待值 の分布として与えられるため, 情報量の多い解となる. $\lambda$ の值が低い場合, 全体的にファジィ期待值は高い值を 与える傾向にある. その反対に $\lambda$ の值が高い場合は, ファジィ期待值は低い值を与える.これは， $\lambda$ の值が高 くなると評価レベルを明確に示し, その反対に $\lambda$ の值が 小さい場合は, 評価レベルをよりあいまいにする傾向に ある17,18).

d）対象とする景観の全体評価レベルの決定

得られた各全体評価レベル $L$ ごとのファジィ期待值 $F(L)$ から, 対象とする景観の全体評価レベル $D_{L}$ を決定 する. 本景観評価機能では, 非ファジィ化の方法として, 式（8）に示す各ファジィ期待值の重心を求めることに より対象とする景観の全体評価レベル $D_{L}$ を決定した. つまり, 重心を求めることにより, 離散量である全体評 価レベルを連続量として計算することが可能となる. $0.0 \sim 1.0$ の時は評価レベル I, $1.0 \sim 2.0$ の時は評価レ ベル II, 2.0〜3.0 の時は評価レベルIII, 3.0〜4.0の時は 評価レベルIV, 4.0〜 5.0 の時はV と設定し, 求められた 各ファジィ期待值をその中央値に割り当てた.

$$
D_{L}=\sum_{L=1}^{5}[F(L) \cdot(L-0.5)] / \sum_{L=1}^{5} F(L)
$$

前記の例では, 表一7, 及び式(8)から対象とする景観の 全体評価レベル $D_{L}$ は 2.013 の值を与える.

\section{(4) 景観評価機能の考察}

写真一4にファジィ理論で評価された結果の出力画面 を示している. 写真一4 から, 作成された景観パースは, 周囲景観との調和と舗装材の性能でレベルIVを与えてい るが，他の各評価項目は，レベル V を与えている. 式 （7）から得られたファジィ積分による全体評価レベル 


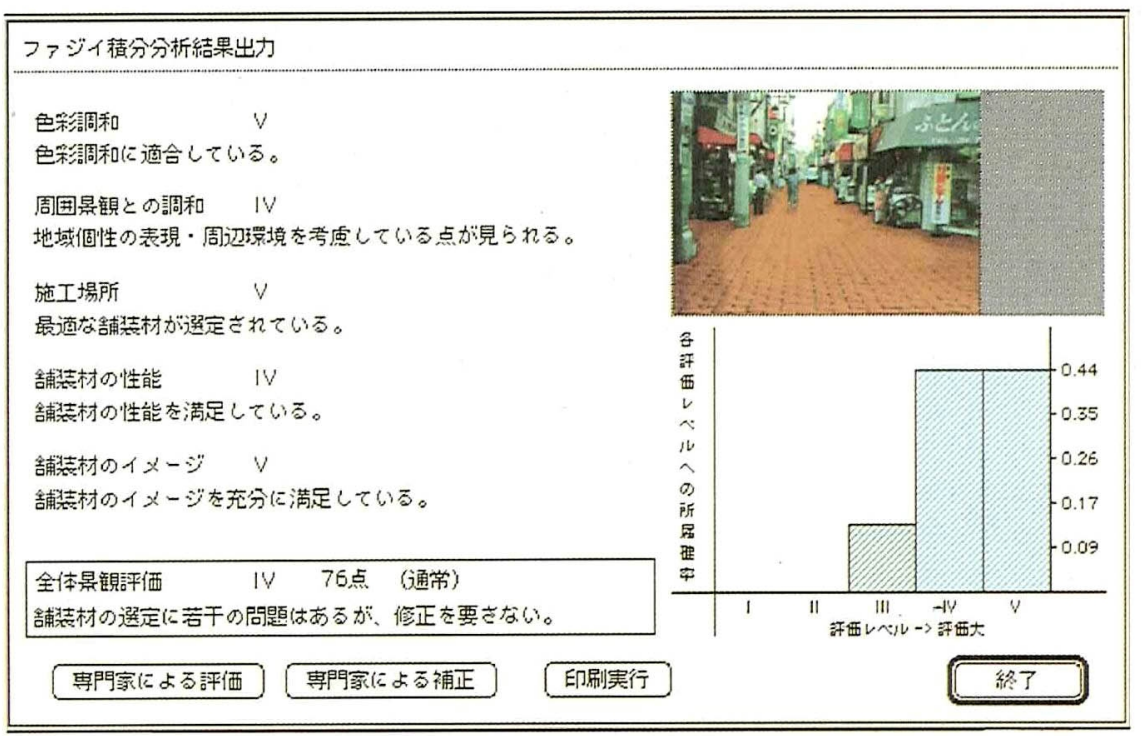

写真一4ファジィ理論で評価された景観評価の出力画像 (イメージ)

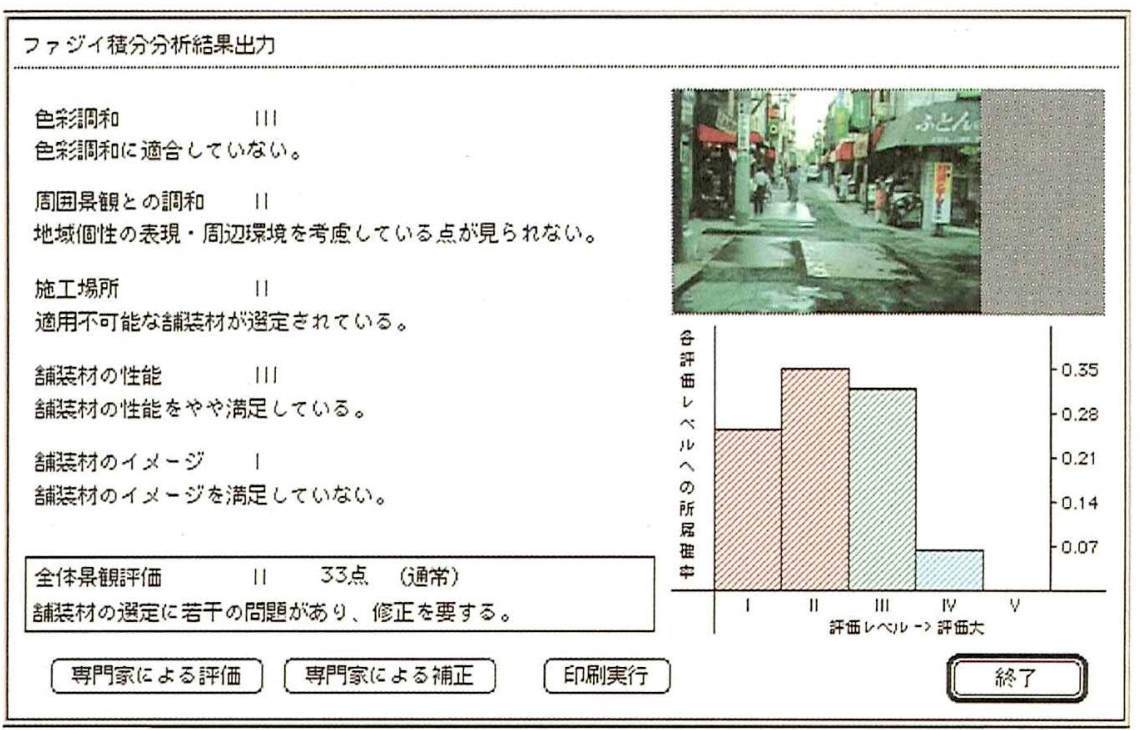

写真一5 ファジィ理論で評価された僦観評価の出力画像（現状）

Lのファジィ期待值は，12\%がレベルIIIに，44\%がレベ ルIVとVに位置する值を示している. そして, 全体評価 レベルでは, 式 $(8)$ から, 3.8 の值 $(\lambda=0)$ を与えレベ ルIVに位置している. 出力画面上では, 対象とする景観 の全体評価レベルを 100 満点で換算した值 $\left(D_{L} \times 20\right)$ で 示すようになっており，ここでは 76 点を与える.

一方, 現在の舗装状態で景観評価を行った出力画面を 写真一 5 に示す. 写真一 5 では, 各評価項目に対して低い レベルを与えており，対象とする景観の全体評価の評価 レベルむレベル II（33 点）と低いレベルを与えている. したがって，この景観舗装材料を用いた路面改修は，景 観度の向上といった点で満足できる（全体評価値は 33
点〜76 点) 設計であると判断できる.

このように，全体評価レベルを確定值のみではなく， 全体評価レベルの期待值の分布によって示すことから評 価に関するばらつきを考虑することが可能である.

\section{結 論}

設計者に対して以下のことを全面支援する景観舗装デ ザイン支援システムの開発を行った。

（1）景観舗装に対して，専門知識のないユーザでも， データベースに構築された属性データから専門家の知識 を共有することにより，施工場所や利用者のニーズを満 足する景観舗装材料を提示することが可能である。 
（2）景観パース図を作成することにより，設計段階で の打ち合わせの時に生じる認識の差を軽減することが可 能となる，また，CG で景観パース図を作成することか ら，景観舗装材料や，その色の変更が容易である。 その ため,・景観パース図の作成に要する時間を大きく軽減す ることが可能である.

（3）景観評価機能では，1)のデータベース機能と同様 に専門家の知識の共有が可能である. また，景観評価に ファジィ理論を用いているため，定量的な決定論ではな く，主観的な決定論により評価される．そのため，評価 に関するばらつきを考慮することが可能となる.

しかしながら，現段階ではファジィ形状や重要度は， 筆者らの経験的な判断により設定したものであり必ずし も正解值とはいい難い。 また，本システムは，自然石， ブロックなどの敷設パターンのデザインに対して, 目地 パターンのイメージまでを含めた評価を行うことは不可 能である，今後は，さらに景観評価に関するプロセスの 調查を行い, その結果から逆解析などを行うことによ り, ファジィ形状や重要度の設定に関する問題を解決し ていく方針である ${ }^{19}$.

\section{謝 辞}

システム設計に関しては,（株）構造計画研究所創造工 学研究室の服部正太氏, 猿渡青児氏には議論に加わって 頂きました．ここに深く感謝の意を表します。

\section{参 考 文 献}

1）土橋正彦・榊原和彦・為国かおる：コンピュータグラ フィックスを利用した景観手法に関する研究，土木学会 第 46 回年次学術講演会, IV-230, pp. 470 471, 1991 年 9 月。

2）武井幸久：街路景観の評価とイメージ・スケール，土木 学会第 47 回年次学術講演会, IV-53, pp. 150 151, 1992 年 9 月.

3）白石成人・古田均・橋本光行：プロダクションシステム を用いた構造物の健全度評価，第 7 回設計における信頼 性工学シンポジゥム，日本材料学会， pp. 164〜169, 1985. 12.

4）白石成人・古田均・池島賢治：信頼性解析へのファジィ 理論の適用に関する基礎的研究, 土木学会論文報告集,
第 325 号, pp. 1 10, 1982. 9.

5）清水則一・桜井春輔：ファジィ理論を用いた岩盤分類の 構成手法に関する研究，土木学会論文報告集，第 307 号， III -5 , pp. $225 \sim 232,1986$. 6 .

6）松島学・関博・松井邦人・梅原健二：ファジィ理論に基 づいた海岸施設の劣化診断, 土木学会論文集, 第 433 号, V-15, pp. 111 118, 1991. 1 .

7）姫野賢治・菅原照雄・八谷好高：Fuzzy 数量化理論 II 類を用いた舗装の路面評価に関する研究，土木学会第 45 回年次学術講演会, V-9, pp. 44 45. 1990 年 9 月.

8）姫野賢治・川村和幸・相馬幸六：主観を取り入れた道路 舗装の路面評価に関する研究, 土木学会第 46 回年次学 術講演会, V-11，pp. 38～39，1991 年 9 月.

9）景観舗装ハンドブック (案)，景観舗装材料に関する検討 委員会, 1992 年 6 月.

10）日本建材産業協会：景観材料の色彩評価の検討（平成 3 年度景観材料色彩評価検討委員会報告), 1992 年 3 月.

11）インターロッキングブロック協会；インターロッキング ブロック舗装研究委員会：インターロッキングブロック 舗装設計施工要領, 1987 年 10 月.

12）（財）土木研究センター，インターロッキングブロック協 会：インターロッキングブロック舗装設計施工要領（車 道編)，1990 年 10 月.

13）建設大臣官房官庁営繥部監修：構内舗装設計標準，（社） 営繕協会, 1989 年.

14.) "Photoshop User's Guide" : Adobe System Inc., 1993

15) "Studio32 User's Guide" : Elecronic Arts, 1992.

16）日本色彩研究所：新基本色表シリーズ No.12 色彩調和, 日本色研事業株式会社, 1987.

17）菅野道夫：Fuzzy 測度と積分，計測自動制御学会論文 集, 第 8 巻, 第 2 号, pp. 218 226, 1972.

18）菅野道夫：Fuzzy 測度の構成とFuzzy 積分によるパ ターンの類似度評価, 自動計測制御学会論文集, 第 9 巻, 第 3 号, pp. $361 \sim 368,1984$.

19）安田登・近田康夫・松島学・木下真二：ファジィ理論に 基づく緑化されたコンクリート構造物の景観評価の逆解 析，第 3 回システム最適化に関するシンポジゥム，土木 学会 AL 技術の構造システム最適化への応用に関する研 究小委員会, 1993 年 12 月.

20）鈴木敏：景観舗装の知識，博報堂出版，1992 年 6 月。

21）田中英雄：ファジィ理論と応用, ファジィ測度に基づく ファジィモデルとその応用, 数理科学, No. 284, pp. 19 $\sim 25,1987.2$.

22）田崎栄一郎：ファジィ・エキスパートシステム，数理科 学, No.284, pp. 46 54, 1987. 2.

23) "Computer-Aided Design and Drafting Systems" NCHRP Synthesis of Highway Practice 161, TRB 1990. Aug.

24）菅野道夫：ファジィ理論の展開一科学における主観性の 回復一，サイエンス社, 1991 年 2 月.

(1993.10.26 受付)

\section{DEVELOPMENT OF COMPUTER ASSITED LANDSCAPE PAVEMENT DESIGN SYSTEM BASED ON FUZZY SET THEORY}

\section{Naoki MIZUNO, Manabu MATSUSHIMA and Masaru MIZOBUCHI}

Today's pavement design requiers a consideration of aesthetis which brings about attractiveness and comforts through harmonizing with the environment that surrounds pavement. Viewing such social request, this paper aims the development of design suppourting system on which engineers can evolve thier design ideas. The system consists of three subsystems ; 1)constuction of pavement materials data base, 2)computer graphics to demonstrate their designs, and 3)a rating system to evaluate designs. Fuzzy Set theory is utilized for a synthetic evaluation of design candidates. 